\title{
Effects of different levels of mulch and irrigation on growth traits and essential oil content of basil
}

\author{
Fatemeh Nejatzadeh-Barandozi \\ Department of Horticulture, Faculty of Agriculture, Islamic Azad University, Khoy Branch, Khoy, Iran
}

\begin{abstract}
Ocimum basilicum L. is an herbaceous plant from the Labiate family that used fresh, as a spice, and as a medicinal plant. Mulch is technique capable of reducing evaporation from the surface of the soil in basil production systems; it has more impacts on yield and essential oil quality of a basil crop. This research was performed in order to study the effects of different mulch types and irrigation regimes on various growth parameters and the essential oil content of basil. Treatments included two mulch types (black plastic, wood chips, and control) and three irrigation levels (100, 80 , and $60 \%$ of water requirements, calculated by evaporation pan class A), following a randomised complete block design with four replications. Results showed that the effect of irrigation on fresh weight, dry weight, leaf relative water content, leaf area, and essential oil yield was significant $(\mathrm{P}<0.05)$. The effect of mulch on fresh weight, dry weight, leaf area, inter-node distance, number of branches, and essential oil yield was significant $(\mathrm{P}<0.05)$. Interaction between irrigation and mulch on inter-node distance, fresh weight, dry weight, and leaf area was significant $(\mathrm{P}<0.05)$. This study identified wood chips as the best mulch treatment. The highest dry weight yield (38.35 g/plant) and the highest essential oil yield $(82.83 \mathrm{~L} / \mathrm{ha})$ resulted when wood chip mulch was used in combination with irrigation at $100 \%$ of the water requirement. This combination also resulted in the highest water productivity in basil production.
\end{abstract}

Correspondence: Fatemeh Nejatzadeh-Barandozi, Department of Horticulture, Faculty of Agriculture, Islamic Azad University, Khoy Branch, P.O. Box 58168-44799, Khoy, Iran.

Fax: +98.4434640001 .6$

E-mail: fnejatzadeh@yahoo.com

Key words: Ocimum basilicum L.; water requirement; mulch; essential oils.

Received for publication: 13 March 2019.

Revision received: 24 August 2019.

Accepted for publication: 16 October 2019.

${ }^{\circ}$ Copyright: the Author(s), 2020

Licensee PAGEPress, Italy

Italian Journal of Agronomy 2020; 15:1247

doi:10.4081/ija.2020.1247

This article is distributed under the terms of the Creative Commons Attribution Noncommercial License (by-nc 4.0) which permits any noncommercial use, distribution, and reproduction in any medium, provided the original author(s) and source are credited.

\section{Introduction}

Recent climate change investigation has reported that global escalation of storms, flooding and other severe weather episodes with growing temperatures may ultimately disrupt crop production (Farhad et al., 2013). Global circulation models projected an increase of $4-5.8^{\circ} \mathrm{C}$ in the surface air temperatures over the next few decades. From 1979 to 2003 , an increase of 0.35 and $1.13^{\circ} \mathrm{C}$ have already documented in the annual mean maximum and minimum temperatures respectively (Farhad et al., 2016a). These temperature increases have likely exposed crops globally to drought induced stress (Farhad et al., 2016c). Drought is recognised as one of the most prominent conditions affecting Iran's geography; however, it is also recognised that irrigation - the primary relief from drought - is not a natural process and in fact taxes an irreplaceable natural resource. Simultaneously, society's consumption of energy resources, water, and food is increasing. Severe droughts cause substantial decline in crop yields through negative impacts on plant growth, physiology, and reproduction (Fahad et al., 2017). Therefore, it will be useful and fruitful to: i) adopt more sustainable agricultural techniques, including sustainable use of water, proper cropping styles, and sowing of resistant plants; ii) recognise the relationship between soil water deficit and plant growth at each stage; and iii) examine the plant's morphological responses to stress (Kochaki and Nasiri Mahallati, 2000; Fahad and Bano, 2012; Farhad et al., 2016b; Aziz et al., 2017a). Plants are sessile beings, so the need of mechanisms to flee from unfavourable circumstances has provided the development of unique and sophisticated responses to environmental stresses. Depending on the degree of plasticity, many morphological, cellular, anatomical, and physiological changes occur in plants in response to abiotic stress (Farhad et al., 2014a; Farhad et al., 2014b; Farhad et al., 2016c; Farhad et al., 2016d). Many researchers have argued that water loss due to evaporation is sufficiently significant, so as to support the premise that water use performance and efficiency could be increased by any management technique capable of reducing evaporation from the surface of the soil (Farhad et al., 2015a; Farhad et al., 2015b). One of the several methods for reducing evaporation from the soil surface is the use of mulch. Mulch is defined as any natural or artificial material used for purposes including the covering of soils, green spaces, and agricultural fields. Plastic covers are widely used throughout the world, including in Iran, because of their low cost and ready availability. Perhaps no technology has ever changed the world's vegetables as much as the use of plastic in agriculture (Mitchell and Yang, 2001; Aziz et al., 2017b). The World Bank reported that from 1989 to 2009 in China, the level of plastic cover in agriculture increased from 44 hectares to two million hectares (Jensen and Malter, 2009). With average rainfall of $250 \mathrm{~mm}$ per year, Iran is classified among the arid and semi-arid regions of the world. Calcareous soils, such as Inceptisols, Entisols, Alfisols and Vertisols, are most 
abundant in arid and semi-arid zones of the world (Adnan et al., 2018). The lack of adequate rainfall and its uneven distribution during the growing season leads to a lack of adequate water for crop needs. It is inevitable, therefore, that Iranian dairy farming is exposed to drought stress; in especially dry years, the water deficit must be compensated through irrigation in order to produce satisfactory yield. Significant research has been done in various countries regarding the effects of mulching and irrigation on plant growth. The use of organic soils helps to improve soil moisture content and regulate soil temperature, microorganism populations, and food mobility, all of which can have a beneficial effect on the performance of aromatic herbs (Ram et al., 2006). Knowledge of the dynamics of plant nitrogen $(\mathrm{N})$ uptake at varying irrigation water levels is critical for strategizing increased $\mathrm{N}$ recovery efficiency (NRE), water use efficiency (WUE), and maize yield. Nitrogen concentration in the stem and grain was linearly increased by increasing $\mathrm{N}$ fertiliser rates with irrigation water. However, in the root, $\mathrm{N}$ concentration was decreased when the crop was supplied with $100 \%$ FC. In plant, maximum N uptake $(6.5 \mathrm{mg} / \mathrm{g})$ was observed when $4.8 \mathrm{~g} \mathrm{~N} /$ pot was applied with $100 \%$ FC. Nitrogen recovery efficiency was increased by increasing $\mathrm{N}$ rate up to $3.2 \mathrm{~g} /$ pot with $100 \% \mathrm{FC}$. Therefore, for achieving maximum WUE and NRE, the highest water and $\mathrm{N}$ applications, respectively, are not necessary (Hafiz et al., 2016). Among the different plastic mulches, black plastic mulches produced the highest percentage of soluble solids $(8.73 \%)$ in comparison with unpolluted soil (7.5\%) (Ram et al., 2006). Plastic mulches have been shown to greatly increase soil temperature and influence the air around the plant and its yield. In addition, the increase in yield and early maturity in plants with plastic mulches was greater than control plants (Ram et al., 2006). Research on irrigation has shown that the highest dry weight and essential oil yields in mint were obtained by repeated irrigation $(50 \mathrm{~mm}$ of evaporation from the evaporation pan) and the application of soil and nitrogen fertiliser (Saxena and Singh, 2005). For melon, the marketable yield was increased through use of plastic mulches in greenhouse drip irrigation that provided $75 \%$ of the plant's water requirement. When maximum irrigation was provided ( $100 \%$ of the water requirement), there was a significant difference between the productions in the uncovered and mulched soil was observed, but the highest water use efficiency was obtained in mulched soils (Castila et al., 2008). A study that applied different levels of water to a West Indian tomato crop concluded that the best combination was drip irrigation with soil containing sugarcane residues and water consumption of $40 \%$ evaporation from the evaporation pan. This treatment demonstrated a $53 \%$ increase in yield, $44 \%$ water savings, the highest irrigation water use efficiency $\left(163 \mathrm{~kg} / \mathrm{m}^{3}\right)$, and $59 \%$ weed reduction compared to non-soak waterlogging (Shrivastava et al., 2004). High irrigation in mint (Mentha arvensis L.) produced the highest yield of essential oil and dry matter (Mitchell and Yang, 2001). One of the optimal effects of irrigation in different mint species is the essential oil yield of plant shoots. Studies have shown that irrigation requirements in mint vary geographically and depend on soil type, soil fertility, and climate factors. (Ram et al., 2006). The results of Turan et al., (2018) indicates that $\mathrm{BC} 0.75 \%+\mathrm{CH} 0.75 \%$ treatment can be used to reduce mobility and bioavailability of heavy metals in SPHIW and facilitates plant growth by improving the antioxidant system. Also, results demonstrated the reduction of nickel (Ni) toxicity and enhancing zinc $(\mathrm{Zn})$ bioavailability from sunflower seed with biochar $(\mathrm{BC})$ and chitosan $(\mathrm{CH})$ application to Ni contaminated soil (Turan et al., 2017). Use of organic manures for soil amendment has gained renewed attention with growing concerns about sustaining soil productivity (Sönmez et al., 2016).

Basil (Ocimum basilicum L.) is an herbaceous plant from the Labiatae family that used fresh, as a spice, and as a medicinal herb. Due to its active ingredients, basil has been introduced as a medicinal plant in many pharmacopoeias (Omidibi and Sarvestani, 2010; Chevallier, 2005). Basil essential oil contains a large amount of estragole or methyl chavicol, linalool, cineole, methyl cinnamate, and eugenol (Omidibi and Sarvestani, 2010). Essential ingredients in its essential oils are used in the perfume, cosmetics, pharmaceutical, and food industries (Harisaranraj et al., 2008). The growth, development, and amount of active ingredients in medicinal plants are affected by environmental humidity. Often, even mild drought stress in plants can significantly affect the growth and development of these products, impacting key processes (Pirzad et al., 2008). Since one of the main problems in the development of basil culture is its high water requirement, its yield depends on irrigation. However, due to the fact that there is a shortage of water resources in our country, one of the solutions to these problems is the implementation of applied research in this field. Therefore, in this research, the effect of different mulch types and different irrigation regimes on physiological and essential oil content of basil were investigated.

\section{Materials and methods}

This research was performed in order to study the effects of different mulch types and irrigation regimes on various growth parameters and the essential oil content of basil (Ocimum basilicum L.) in 2015 at Agricultural Faculty of Islamic Azad University of khoy located north of $38^{\circ}$ and 36 min north and $45^{\circ}$ and 16 min east longitude and its elevation of the sea was 1103 meters. Based on the region's meteorological data in the first six months of 2015, the annual rainfall is $290 \mathrm{~mm}$, the average temperature is $13.4^{\circ} \mathrm{C}$, the average relative humidity is $36.69 \%$, and the average wind speed is $2200 \mathrm{~m} / \mathrm{s}$. For this purpose, in April, the land preparation was done and then land was planted. Land were prepared with dimensions of $1.5 \times 2 \mathrm{~m}$. After placement of black plastic mulch (black polyethylene), seedlings were planted. In wood chips, the seeds were planted on the ground after determining the percentage of soil compositions (Table 1). The particle size of wood chips used in this experiment was $8-5$ $\mathrm{cm}$. Treatments included three irrigation levels $\mathrm{I}_{1}$ : $100 \%$ water requirement, $\mathrm{I}_{2}: 80 \%$ water requirement, $\mathrm{I}_{3}: 60 \%$ water requirement, and two types of mulches (black plastic, wood chips) and control. This experiment was conducted as factorial in a randomised complete block design with 9 treatments and 4 replications. Irrigation of plants was carried out every 4 days according to soil analysis (Table 2) and evaporation data from evaporation pan. Also, the total amount of irrigation water during the irrigation stress period was calculated for determining the water productivity index (Table 3). Weed control was

Table 1. Chemical composition of mulch based on dry weight.

\begin{tabular}{lcccccccc} 
Mulch type & $\begin{array}{c}\text { Protein } \\
(\%)\end{array}$ & $\begin{array}{c}\text { Ash } \\
(\%)\end{array}$ & $\begin{array}{c}\text { Fat } \\
(\%)\end{array}$ & $\begin{array}{c}\text { Crude filbre } \\
(\%)\end{array}$ & $\begin{array}{c}\text { Carbohydrate } \\
(\%)\end{array}$ & $\begin{array}{c}\text { Organic carbon } \\
(\%)\end{array}$ & $\begin{array}{c}\text { Nitrogen } \\
(\%)\end{array}$ \\
Wood chips & 2.60 & 1.90 & 1.1 & 31.5 & 28.89 & 28.32 & 0.25 \\
\hline
\end{tabular}


carried out by hand. No weed was observed in treatments with soil cover. Data were collected by measuring the distance between nodes, number of flowers per plant, number of branches, plant height, fresh and dry weight, chlorophyll index using a manual chlorophyll meter, using the method of presentation (RWC), leaf area, essential oil content and yield of essential oil were investigated. At the time of flowering, the first harvest was taken. Essential oils from different treatments at full flowering stage after drying in shade were extracted by water distilled in Kelvenger for $4 \mathrm{~h}$.

\section{Data statistical analysis}

For statistical analysis and analysis of variance, MSTAT-C software was used. LSD test was used at 5\% level to compare the means.

\section{Results}

\section{Distance between nodes}

Analysis of variance showed that mulch was significant effect at $5 \%$ level and interaction of irrigation and mulch was significant at $1 \%$ level (Table 3). Comparison of the mean of irrigation data showed that the maximum distance between nodes was $2.825 \mathrm{~cm}$ with the $100 \%$ water requirement (first level of irrigation) and the minimum internally spaced $(2.605 \mathrm{~cm})$ interval with $80 \%$ water requirement (second level of irrigation) (Table 4). The comparison of mean values of mulch data showed that the maximum distance between nodes was $2.90 \mathrm{~cm}$ (with the use of wood chips mulch and the lowest with $2.55 \mathrm{~cm}$ in control treatment). These results showed that wood chips mulch increased $12.28 \%$ compared to control. There was no significant difference between black plastic treatment and control treatment (Table 5). Also, comparison of

Table 2. Physical and chemical composition of the soil.

\begin{tabular}{|c|c|c|c|c|c|c|c|c|}
\hline Texture & $\mathrm{pH}$ & $\begin{array}{c}\text { EC } \\
(\mathrm{ds} / \mathrm{m})\end{array}$ & Available P & Available K & $\begin{array}{l}\text { Total N } \\
\text { (mg/kg) }\end{array}$ & $\begin{array}{c}\text { Organic carbon } \\
\text { (\%) }\end{array}$ & Percent Saturated & Lime \\
\hline Sandy Lomi & 7.83 & 1.40 & 5.3 & 261 & 735 & 0.40 & 25 & 12.1 \\
\hline
\end{tabular}

Table 3. Analysis of variance of different levels of mulch and irrigation on growth traits and essential oil content of basil.

\begin{tabular}{|c|c|c|c|c|c|c|c|c|c|c|c|}
\hline $\begin{array}{l}\text { Source of } \\
\text { variations }\end{array}$ & DF & $\begin{array}{l}\text { Plant } \\
\text { height }\end{array}$ & $\begin{array}{c}\text { Distance } \\
\text { between nodes }\end{array}$ & $\begin{array}{c}\text { Number of } \\
\text { flower }\end{array}$ & $\begin{array}{l}\text { Number of } \\
\text { branches }\end{array}$ & $\begin{array}{c}\text { Fresh weight } \\
\text { of plant }\end{array}$ & $\begin{array}{l}\text { Dry weight } \\
\text { of plant }\end{array}$ & $\begin{array}{l}\text { Chlorophyl } \\
\text { index }\end{array}$ & $\begin{array}{l}\text { Leaf } \\
\text { area }\end{array}$ & $\begin{array}{c}\text { Essential oil } \\
\text { content }\end{array}$ & $\begin{array}{l}\text { Essential oil } \\
\text { yield }\end{array}$ \\
\hline Replication & 3 & 70.675 & 0.234 & 16.790 & 1.149 & 63.781 & 9.159 & 5.021 & 23361.639 & 0.450 & 461.779 \\
\hline Irrigation (A) & 2 & 192.041ns & $0.169 \mathrm{~ns}$ & $73.022 n s$ & $1.889 \mathrm{~ns}$ & $3461.751^{* *}$ & $280.612 * *$ & $18.847 n s$ & $189441.434^{* *}$ & $0.106 \mathrm{~ns}$ & $1323.659^{* *}$ \\
\hline Mulch (B) & 2 & $135.789 \mathrm{~ns}$ & $0.519 *$ & 13.65lns & $26.072 * *$ & $6968.491^{* *}$ & $616.089 * *$ & $1.950 \mathrm{~ns}$ & $263071.564^{* *}$ & $0.097 \mathrm{~ns}$ & $2598.498 * *$ \\
\hline$A \times B$ & 4 & $60.089 \mathrm{~ns}$ & $0.549 * *$ & $29.605 \mathrm{~ns}$ & $1.471 \mathrm{~ns}$ & 1131.010* & $92.314^{*}$ & $3.893 \mathrm{~ns}$ & $82882.024 * *$ & $0.064 n s$ & 428.243ns \\
\hline Error & 24 & 83.710 & 0.125 & 63.601 & 2.596 & 340.610 & 31.243 & 14.677 & 11244.551 & 0.107 & 210.279 \\
\hline CV (\%) & - & 16.45 & 13.26 & 131.71 & 31.63 & 24.21 & 25.05 & 6.46 & 18.80 & 13.79 & 29.31 \\
\hline
\end{tabular}

DF, degree of freedom. ns, ${ }^{*}$ and ${ }^{* *}$, non-significant and significant at the 5 and $1 \%$ levels of probability, respectively.

Table 4. Mean of different levels of irrigation on growth traits and essential oil content of $b$ asil.

\begin{tabular}{|c|c|c|c|c|c|c|c|c|c|c|}
\hline Treatment & $\begin{array}{l}\text { Plant } \\
\text { height } \\
(\mathrm{cm})\end{array}$ & $\begin{array}{c}\text { Distance } \\
\text { between } \\
\text { nodes } \\
(\mathrm{cm})\end{array}$ & $\begin{array}{l}\text { Number of } \\
\text { flower }\end{array}$ & $\begin{array}{l}\text { Number of } \\
\text { branches }\end{array}$ & $\begin{array}{l}\text { Fresh } \\
\text { weight } \\
\text { of plant } \\
\text { (g) }\end{array}$ & $\begin{array}{l}\text { Dry } \\
\text { weight } \\
\text { of plant } \\
\text { (g) }\end{array}$ & $\begin{array}{c}\text { Chlorophyll } \\
\text { index }\end{array}$ & $\begin{array}{l}\text { Leaf } \\
\text { area } \\
\left(\mathrm{cm}^{2} / \mathrm{p}\right)\end{array}$ & $\begin{array}{c}\text { Essential } \\
\text { oil } \\
\text { content } \\
(v / w \%)\end{array}$ & $\begin{array}{c}\text { Essential } \\
\text { oil } \\
\text { yield } \\
\text { (L/ha) }\end{array}$ \\
\hline $\mathrm{I}_{1}$ & $60.65^{\mathrm{a}}$ & $2.825^{\mathrm{a}}$ & $8.880^{\mathrm{a}}$ & $5.296^{\mathrm{a}}$ & $89.97^{\mathrm{a}}$ & $26.24^{\mathrm{a}}$ & $57.68^{\mathrm{a}}$ & $705.6^{\mathrm{a}}$ & $2.427^{\mathrm{a}}$ & $60.12^{\mathrm{a}}$ \\
\hline $\mathrm{I}_{2}$ & $53.65^{\mathrm{a}}$ & $2.605^{\mathrm{a}}$ & $4.246^{\mathrm{a}}$ & $4.494^{\mathrm{a}}$ & $57.20^{\mathrm{b}}$ & $16.59^{\mathrm{b}}$ & $58.42^{\mathrm{a}}$ & $476.1^{b}$ & $2.431^{\mathrm{a}}$ & $46.64^{b}$ \\
\hline $\mathrm{I}_{3}$ & $53.70^{\mathrm{a}}$ & $2.630^{\mathrm{a}}$ & $5.021^{\mathrm{a}}$ & $5.022^{\mathrm{a}}$ & $70.89^{b}$ & $22.01^{\mathrm{b}}$ & $58.32^{\mathrm{a}}$ & $502.2^{b}$ & $2.265^{\mathrm{a}}$ & $46.80^{\mathrm{b}}$ \\
\hline
\end{tabular}

$\mathrm{I}_{1}$, irrigation with $100 \%$ water requirement of plant; $\mathrm{I}_{2}$, irrigation with $80 \%$ of plant water requirement; 13 , Irrigation to $60 \%$ of plant water requirement. a-bIn each column, the same letters indicate that there is no significant difference b etween the meanings (LSD test).

Table 5. Mean of different levels of mulch on growth traits and essential oil content of basil.

\begin{tabular}{|c|c|c|c|c|c|c|c|c|c|c|}
\hline Treatment & $\begin{array}{l}\text { Plant } \\
\text { height } \\
(\mathrm{cm})\end{array}$ & $\begin{array}{c}\text { Distance } \\
\text { between } \\
\text { nodes } \\
(\mathrm{cm})\end{array}$ & $\begin{array}{c}\text { Number of } \\
\text { flower }\end{array}$ & $\begin{array}{l}\text { Number of } \\
\text { branches }\end{array}$ & $\begin{array}{l}\text { Fresh } \\
\text { weight } \\
\text { of plant } \\
\text { (g) }\end{array}$ & $\begin{array}{l}\text { Dry } \\
\text { weight } \\
\text { of plant } \\
\text { (g) }\end{array}$ & $\begin{array}{l}\text { Chlorophyll } \\
\text { index }\end{array}$ & $\begin{array}{l}\text { Leaf } \\
\text { area } \\
\left(\mathrm{cm}^{2} / \mathrm{p}\right)\end{array}$ & $\begin{array}{c}\text { Essential } \\
\text { oil } \\
\text { content } \\
(\mathrm{v} / \mathrm{w} \%)\end{array}$ & $\begin{array}{c}\text { Essential } \\
\text { oil } \\
\text { yield } \\
\text { (L/ha) }\end{array}$ \\
\hline Wood chips & $59.12^{\mathrm{a}}$ & $2.90^{\mathrm{a}}$ & $6.910^{\mathrm{a}}$ & $6.605^{\mathrm{a}}$ & $99.1^{\mathrm{a}}$ & $29.41^{\mathrm{a}}$ & $58.20^{\mathrm{a}}$ & $714.1^{\mathrm{a}}$ & $2.340^{\mathrm{a}}$ & $65.12^{\mathrm{a}}$ \\
\hline B lack plastic & $56.51^{\mathrm{a}}$ & $2.56^{\mathrm{b}}$ & $6.383^{\mathrm{a}}$ & $3.690^{\mathrm{b}}$ & $63.89^{\mathrm{b}}$ & $18.57^{\mathrm{b}}$ & $58.67^{\mathrm{a}}$ & $550.4^{\mathrm{b}}$ & $2.476^{\mathrm{a}}$ & $43.50^{\mathrm{b}}$ \\
\hline No cover (control) & $52.42^{\mathrm{a}}$ & $2.55^{\mathrm{b}}$ & $4.856^{\mathrm{a}}$ & $4.517^{\mathrm{b}}$ & $53.30^{\mathrm{b}}$ & $15.86^{\mathrm{b}}$ & $59.56^{\mathrm{a}}$ & $418.5^{\mathrm{c}}$ & $2.306^{\mathrm{a}}$ & $36.97^{\mathrm{b}}$ \\
\hline
\end{tabular}

a-cIn each column, the same letters indicate that there is no significant difference between the meanings (LSD test). 
mean interactions between irrigation and mulch on distance the nodes showed that the maximum internally spaced with $3.486 \mathrm{~cm}$ in the first irrigation treatment $(100 \%$ water requirement) with the wood chips mulch and the least distance the nodes was $2.423 \mathrm{~cm}$ in the second level irrigation treatment ( $80 \%$ water requirement) with wood chips obtained (Figure 1).

\section{Number of branches}

The results of variance analysis of number of branches showed that the effect of mulch on this trait was significant at $1 \%$ level (Table 3). So that the highest number of branches was 6.605 with the use of wood chips mulch and the least of it was 3.690 in black plastic treatment. The results showed that the number of branches increased to $44.11 \%$ in the woodchips compared to the black plastic mulch. Also, the difference between woodchip mulch with two black and uncovered plastic treatments was significant (Table 4). Comparing the interaction between irrigation and mulch on the number of branches, the highest number of branches was 7.162 with the use of wood chips mulch and the first level of irrigation, and there was no significant difference between the wood chips mulch and the first level of irrigation with the wood chips mulch and the third level of irrigation. Of course, the minimum number of branches was 3.412 with black plastic treatment and the third level of irrigation. These results showed that the wood chips mulch with the first level of irrigation increased the number of branches by $52.33 \%$ compared to the black plastic mulch with the third level of irrigation (Table 5).

\section{Fresh weight of the plant}

The results of variance analysis of studied traits showed that irrigation and mulch had significant effect on fresh weight at $1 \%$ level, as well as interaction between irrigation and mulch on this trait was significant at 5\% level (Table 3). Comparison of the mean of the results showed that the first level of irrigation $(100 \%$ of the water requirement), produced the highest fresh weight of $97.98 \mathrm{~g}$ There was no significant difference between the second and third levels of irrigation (Table 4). The effect of mulch on this trait showed that the highest fresh weight was $1.99 \mathrm{~g}$ with wood chips mulch. There was no significant difference between black plastic mulch and control (Table 5). The comparison of mean interactions between irrigation and mulch on fresh weight showed that the highest fresh weight $(125.8 \mathrm{~g})$ was obtained by the treatment of wood chips mulch and first level irrigation, and the lowest fresh weight was $(45.03 \mathrm{~g})$ with control treatment and second level irrigation was observed. However, interaction of wood chips and the first level of irrigation, fresh weight increased $63.31 \%$ compared to the control with the second level of irrigation) $80 \%$ of the water requirement of the plant ((Figure 2).

\section{Dry weight of the plant}

The results presented in (Table 3) showed that, irrigation had significant effect on plant dry weight at $1 \%$ level, so that the highest dry weight $(26.24 \mathrm{~g})$ was observed in the first level irrigation treatment (Table 4). Mulch effect on this trait was significant at $1 \%$ level and the highest dry weight was $41.49 \mathrm{~g}$ with the use of wood chips mulch (Table 5). Interaction between irrigation and mulch was significant at $5 \%$ level (Table 3 ). The highest dry weight was $37.37 \mathrm{~g}$ with the interaction of wood chips and the first level of irrigation. The first irrigation level and the third level of irrigation and wood chips were in a statistical group. Also, the lowest dry weight was $13.85 \mathrm{~g}$ with control treatment and the second level of irrigation (Figure 3). Based on the results, dry weight decreased about $61.23 \%$ with third level of irrigation and control treatment than wood chips and the first level of irrigation. The results of analysis of variance of leaf area showed that different levels of irrigation and mulch as well as interaction effect was significant at $1 \%$ level (Table 3).

\section{Leaf area}

The highest leaf area was $705.6 \mathrm{~cm}^{2}$ in the first irrigation treatment and the lowest leaf area was $477.1 \mathrm{~cm}^{2}$ in the second level of irrigation treatment, which was $32.48 \%$ higher than the first level

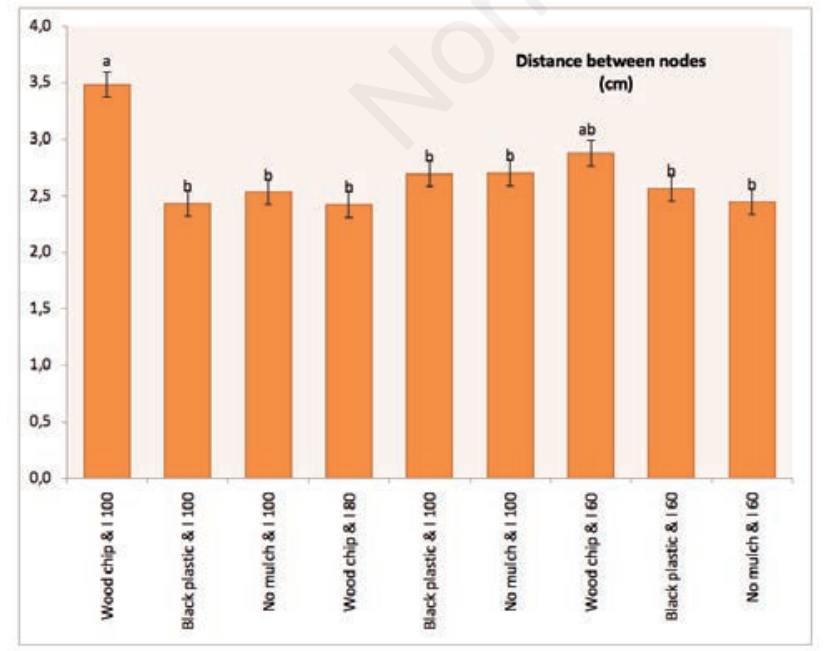

Figure 1. The interaction of different levels of irrigation and mulch on the distance between nodes of (Ocimum basilicum L.). In each column, the same letters indicate that there is no significant difference between the meanings.

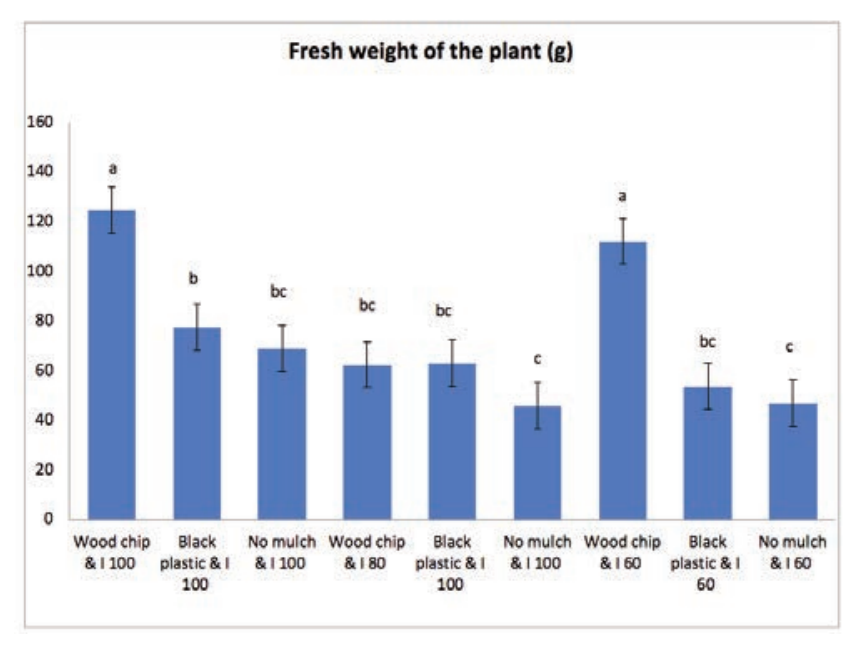

Figure 2. The interaction of different levels of irrigation and mulch on Fresh weight of (Ocimum basilicum L.). In each column, the same letters indicate that there is no significant difference between the meanings. 
of irrigation (Table 4). The effect of mulch type on this trait showed that the highest leaf area of $714.1 \mathrm{~cm}^{2}$ was obtained by using wood chip mulch and the minimum leaf area was $414.5 \mathrm{~cm}^{2}$ with control treatment. Wood chip mulch increased leaf area by $41.33 \%$ to control treatment. Also, the difference between all three types of mulch was significant (Table 5). Comparison of mean values of leaf area in interaction of irrigation and mulch showed that the highest leaf area of $835 \mathrm{~cm}^{2}$ was by using the interaction of wood chips and the first level of irrigation and the lowest leaf area with $377.3 \mathrm{~cm}^{2}$ with irrigation and control treatment was achieved. However, no significant difference was observed between wood chips mulch and first level irrigation treatments with wood chips mulch, and second level irrigation and black plastic mulch and first level of irrigation (Figure 4).

\section{Essential oil yield}

Analysis of variance showed that irrigation and mulch on essential oil yield was significant at $1 \%$ level (Table 3 ). The comparison of mean values in this trait showed that the highest level of essential oil yield was obtained from the first level of irrigation (12.61 L/ha) (Table 4). The effect of mulch type showed that the highest yield of essential oil was obtained $12.65 \mathrm{~L} /$ ha with the use of wood chips mulch (Table 5). Based on the results, essential oil yield increased by $42 \%$ compared to control. The results of analysis of variance showed that interaction between irrigation and mulch was not significant. Effect of different levels of irrigation on essential oil yield showed that the highest essential oil yield of $60.12 \mathrm{~L} /$ ha was the first level irrigation treatment (Table 4). Also effect of different levels of mulch on essential oil yield showed that the highest essential oil yield of $65.12 \mathrm{~L} /$ ha was observed with wood chips mulch (Table 5). The minimum yield of essential oil was achieved with control treatment (Tables 4 and 5).

\section{Number of flowers per plant, plant height, chlorophyll index and essential oil percentage}

Also, the effect of experimental treatments on the traits such as

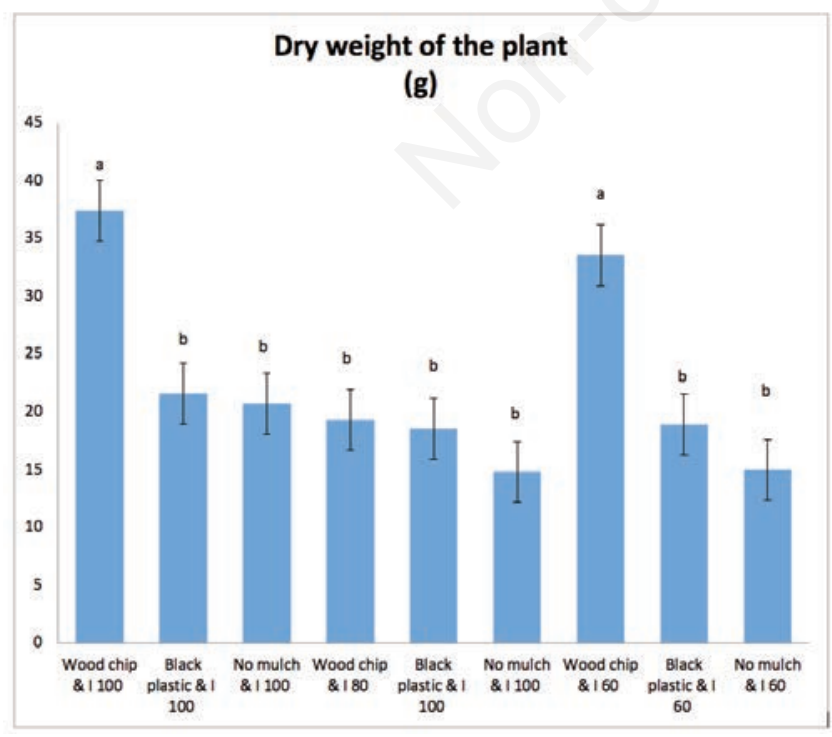

Figure 3. The interaction of different levels of irrigation and mulch on Dry weight of (Ocimum basilicum L.). In each column, the same letters indicate that there is no significant difference between the meanings. number of flowers per plant, plant height, chlorophyll index and percentage of essential oil was not significant (Table 3).

\section{Discussion}

The results of this study are based on the increase of dry matter and yield, correspond with the results of other researchers, on peppermint (Mirsa and Strivastava, 2000) and sage (Baher Nik et al., 2004) and the flower of Mexico (Omidibi and Sarvestani, 2010). The process of decreasing leaf area is also consistent with the decline in yield due to the exacerbation of water scarcity. Reduction of water leads to a decrease in the absorption of the elements, and decrease the growth of the leaves. Therefore, by decreasing leaf area, the level of transpiration of the plant decreases and this is the first mechanism of the plant to cope with drought. Reduction of leaf area, absorption of sunlight and subsequent photosynthesis of the plant decreases and finally leads to a decrease in dry matter production and plant yield (Shrivastava et al., 2004). The results obtained for the traits measured in mint (Mirsa and Strivastava, 2000) correspond to the reported data of Thymus (Johnson, 2000), Basil (Hasani et al., 2003), and Lemon balm (Hassani, 2006). Based on the results obtained in Savory (Baher Nik et al., 2004) and Lemon balm (Abbaszadeh et al., 2008), the relative water content of the leaves decreased. So that the third level of irrigation had the least amount of leaf water content, research on mint revealed that the moisture regime ( $1 / 2$ ratio of irrigation requirement to cumulative evaporation of soils) caused a significant increase in crop growth and number of branches and leaf and yield of mint essence compared to moisture regime was 0.6 and 0.9 (ratio of irrigation requirement to cumulative evaporation) and production of $86.4 \%$ and fresh and $10 \%$ fresh branches and leaves increased compared to two other moisture regimes (Chevallier, 2005; Ram et al., 2006). Also, researchers with other studies showed that irrigation with high levels in mint (Mentha arvensis L.) produced the highest yield of essential oil and dry

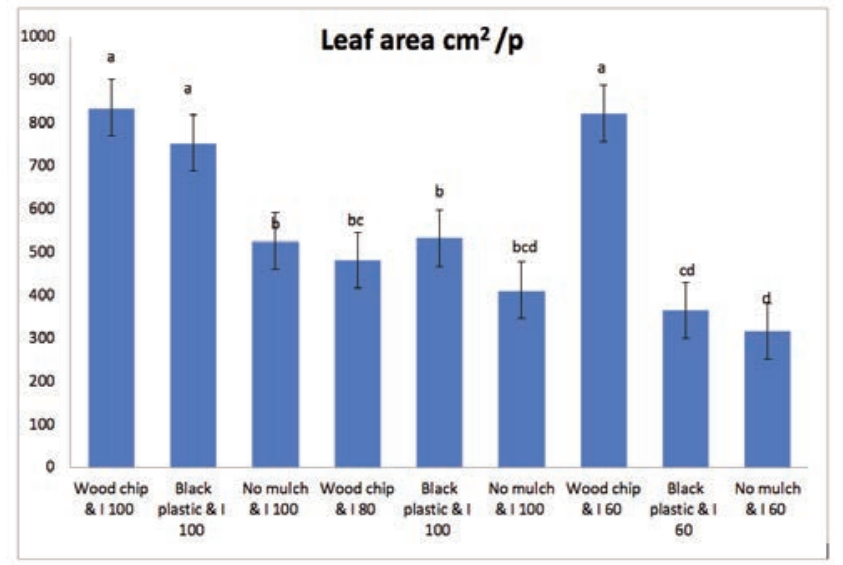

Figure 4. The interaction of different levels of irrigation and mulch on Leaf area of (Ocimum basilicum L.). In each column, the same letters indicate that there is no significant difference between the meanings. 
matter (Mitchell and Yang, 2001). So that results of these researchers are consistent with the results of this research. Investigations carried out in this experiment showed that the use of wood chips mulch caused soil moisture and soil temperature adjustment during basil season, which in turn increased water use efficiency and increased basil yield. These results are consistent with other researchers' findings that the use of organic mulch to improve soil moisture storage, soil temperature regulation, microorganism population and food mobility, all of which have beneficial effects on the yield and increased dry weight of the mint product (Ram et al., 2006). Effect of organic mulch on rice straw and lemon grass leaves on essential oil in Mint showed that dry weight increased by $17 \%$ using rice straw mulch and increased by $32 \%$ with lemon grass leaves. The results showed that straw mulch caused the production of small plants and increased dry matter, which is due to the optimum temperature of the soil and also the maintenance of moisture under the soil of the straw. As the yield of the essential oil depends on the yield of fresh foliage and the amount of essential oil, the yield of the foliage directly influences the essential oil yield under the conditions of application of the mulch. However, the application of mulches had no effect on essential oil content. Also, the application of straw mulch had no effect on the height of cultivated plants but increased the number of small plants, which is effective as dry matter accumulation for mint essence compared to non-mulch treatments (Shao et al., 2008; Singh and Saini, 2008). This increase in the number of cultivated plants, number of branches and accumulation of dry matter can be due to low density and low biomass of weeds and optimum soil temperature (Saxena and Singh, 2005; Farhad et al., 2013) and also higher soil moisture content under the soil. These results are consistent with the results obtained from (Ram et al., 2006; Castila et al., 2008) with present study is consistent. The results of mulch and irrigation showed that the highest dry matter yield of single plant with $41.83 \mathrm{~g}$ was obtained by treatment of wood chips mulch and first level irrigation (100\% water requirement).

\section{Conclusions}

The results of this study showed that the cultivation of Basil in drought condition due to low vegetative yield and consequently the reduction of essential oil yields. Therefore, due to Plants are sessile beings, so the need of mechanisms to flee from unfavourable circumstances has provided the development of unique and sophisticated responses to environmental stresses. Depending on the degree of plasticity, many morphological, cellular, anatomical, and physiological changes occur in plants in response to abiotic stress. Application of mulch could be decreased water loss due to evaporation from the soil surface, so as to support the premise that water use and efficiency of water widely recommended because of their low cost and ready availability for purposes the covering of soils, green spaces, and agricultural fields. However, given that the results showed that wood chips mulch and irrigation water in $100 \%$ of water requirement in basil production, it can be stated that the use of wood chips mulch with maintenance of soil moisture and prevention of evapotranspiration and reducing soil temperature can provide a suitable environment for the growth and increase of the yield of this valuable medicinal plant.

\section{Highlights}

- Different levels of irrigation alone did not always increase plant growth and yield of basil.
- Different levels of mulch alone did not always increase plant growth and yield of basil.

- Different levels of irrigation and mulch in combination used, increased, growth and essential oil yield of basil.

- This study identified wood chips as the best mulch treatment.

- The highest essential oil yield resulted with wood chip mulch and irrigation at $100 \%$ of the water requirement.

\section{References}

Abbaszadeh B, Sharifi Ashourabadi E, Lebaschi MH, Naderi Hajibagher Kandyand M, Moghadami F, 2008. The effect of drought stress on proline contents, soluble sugars, chlorophyll and relative water contents of balm (Melissa officinalis L.). Iranian J. Med Aroma Plants. 23:504-13.

Adnan M, Zahir S, Fahad S, Arif M, Mukhtar A, Imtiaz AK, Ishaq AM, Abdul B, Hidayat U, Muhammad A, Inayat-Ur R, Saud S, Muhammad ZI, Yousaf J, Amanullah Hafiz MH, Wajid N, 2018. Phosphate-solubilising bacteria nullify the antagonistic effect of soil calcification on bioavailability of phosphorus in alkaline soils. Sci. Rep. 8:4339.

Aziz K, Daniel KYT, Fazal M, Muhammad ZA, Farooq S, Fan W, Fahad S, Ruiyang Z, 2017a. Nitrogen nutrition in cotton and control strategies for greenhouse gas emissions: a review. Environ Sci. Pollut. Res. 24:23471-87.

Aziz K, Daniel KYT, Muhammad ZA, Honghai L, Shahbaz AT, Mir A, Fahad S, 2017b. Nitrogen fertility and abiotic stresses management in cotton crop: a review. Environ Sci. Pollut. Res. 24:14551-66.

Baher Nik Z, Rezaee MB, Ghorbanli M, Asgari F, Araghi MK, 2004. Research on the changes of metabolism in response to water stress in Satureja hortensis L. Iranian J. Med Aroma Plants Res. 20:263-75.

Castila N, Gallego A, Cruz-Romero G, 2008. Greenhouse melon response to plastic mulch. ISHS Acta Horticulturae 458: International Symposium on Water Quality and QuantityGreenhouse, Tenerife, Spain.

Fahad S, Bano A, 2012. Effect of salicylic acid on physiological and biochemical characterisation of maize grown in saline area. Pak. J. Bot. 44:1433-8.

Fahad S, Chen Y, Saud S, Wang K, Xiong D, Chen C,Wu C, Shah F, Nie L, Huang J, 2013. Ultraviolet radiation effect on photosynthetic pigments, biochemical attributes, antioxidant enzyme activity and hormonal contents of wheat. J. Food, Agri. Environ.11:1635-41.

Fahad S, Hussain S, Bano A, Saud S, Hassan S, Shan D, Khan FA, Khan F, Chen Y, Wu C, Tabassum MA, Chun MX, Afzal M, Jan A, Jan MT, Huang J, 2014a. Potential role of phytohormones and plant growth-promoting rhizobacteria in abiotic stresses: consequences for changing environment. Environ Sci. Pollut. Res. 22:4907-921.

Fahad S, Hussain S, Matloob A, Khan FA, Khaliq A, Saud S, Hassan S, Shan D, Khan F, Ullah N, Faiq M, Khan MR, Tareen AK, Khan A, Ullah A, Ullah N, Huang J, 2014b. Phytohormones and plant responses to salinity stress: a review. Plant Growth Regul. 75:391-404.

Fahad S, Hussain S, Saud S, Tanveer M, Bajwa AA, Hassan S, Shah AN, Ullah A, Wu C, Khan FA, Shah F, Ullah S, Chen Y, Huang J, 2015a. A biochar application protects rice pollen from hightemperature stress. Plant Physiol. Biochem. 96:281-7.

Fahad S, Nie L, Chen Y, Wu C, Xiong D, Saud S, Hongyan L, Cui 
K, Huang J, 2015b. Crop plant hormones and environmental stress. Sustain Agric. Rev. 15:371-400.

Fahad S, Hussain S, Saud S, Hassan S, Chauhan BS, Khan F, 2016a. Responses of rapid viscoanalyser profile and other rice grain qualities to exogenously applied plant growth regulators under high day and high night temperatures. PLoS One. 11:e0159590.

Fahad S, Hussain S, Saud S, Khan F, Hassan S, Jr A, Nasim W, Arif M, Wang F, Huang J, 2016b. Exogenously applied plant growth regulators affect heat-stressed rice pollens. J. Agron. Crop Sci. 202:139-50

Fahad S, Hussain S, Saud S, Hassan S, Ihsan Z, Shah AN,Wu C, Yousaf M, Nasim W, Alharby H, Alghabari F, Huang J, 2016c. Exogenously applied plant growth regulators enhance the morphophysiological growth and yield of rice under high temperature. Front Plant. Sci.7:1250.

Fahad S, Hussain S, Saud S, Hassan S, Tanveer M, Ihsan MZ, Shah AN, Ullah A, Nasrullah KF, Ullah S, AlharbyH NW, Wu C, Huang J, 2016d. A combined application of biochar and phosphorus alleviates heat-induced adversities on physiological, agronomical and quality attributes of rice. Plant Physiol. Biochem. 103:191-8.

Fahad S, Bajwa AA, Nazir U, Anjum SA, Farooq A, Zohaib A, Sadia S, NasimW, Adkins S, Saud S, Ihsan MZ, Alharby H,Wu C,Wang D, Huang J, 2017. Crop production under drought and heat stress: plant responses and management options. Front Plant. Sci. 8:1147.

Hafiz MH, Wajid F, Farhat A, Fahad S, Shafqat S, Wajid N, Hafiz FB, 2016. Maize plant nitrogen uptake dynamics at limited irrigation water and nitrogen. Environ Sci. Pollut. Res. 24:2549-57.

Harisaranraj R, Prasitha R, Babu SS, Suresh K, 2008. Analysis of Inter-species relationships of Ocimum species using RAPD Markers. Ethnobot. Leaflets. 12: 609-13.

Hasani A, Omid Bighi R, Heydari Sharifabad H, 2003. Effect of different moisture content on growth, yield and accumulation Compatibility Metabolites in Basil Plant. Soil Water Sci. 2:218-28.

Hassani A, 2006. Effect of water deficit stress on growth, yield and essential oil content of Dracocephalum moldavica. Iranian J. Med Aroma Plants. 22:256-61.

Jensen MH, Malter AJ, 2009. Protected Agriculture-A Global Review. World Bank Publications, 157p.

Johnson LUE, 2000. Factors affecting growth and the yield of oil in Spanish thyme (Lippia micromera Schou). University of the
West Indies, St. Augustine, Trinidad, 264p.

Kochaki A, Nasiri Mahallati M, 2000. Ecology of crops, Jalalul, Mashhad University Press. 291 pages.

Mirsa A, Strivastava NK, 2000. Influence of water stress on Japanese mint. J. Herbs Spices Med. Plants. 7:51-8.

Mitchell AR, Yang CL, 2001. Irrigation of peppermint for optimal yield. Soil Sci. Soc. Am. 62:1405-9.

Omidibi R, Sarvestani M, 2010. Effect of drought stress on some morphological traits, volume and function of essential oil of Mexican flower. J. Hort. 41:153-61.

Pirzad AR, Aliari H, Shakiba MR, Zehtab Salmasi SA, Mohammadi SA, 2008. Effects of irrigation and plant density on water consumption efficiency in the production of German chamomile capitol. Agric. Knowledgement. 18:81-91.

Ram D, Ram M, Singh R, 2006. Optimisation of water and nitrogen application to menthol mint (Mentha arvensis L.) through sugarcane trash mulch in a sandy loam soil of semi-arid subtropical climate. Bio Res. Technol. 97:886-93.

Saxena A, Singh GN, 2005. Effect of irrigation, mulch and nitrogen on yield and composition of Japanese Mint (Mentha arvensis L. subsp. haplocalyx var. piperascens) oil. J. Agron. Crop Sci. 175:183-8.

Shao HB, Chu LY, Jaleel CA, Zha CX, 2008. Water-deficit stressinduced anatomical changes in higher plants. Current Res. Biol. 331:215-25.

Shrivastava PK, Parikh MM, Sawani NG, Raman S, 2004. Effect of drip irrigation and mulching on tomato yield. Agric. Water Management. 25:179-84.

Singh MK, Saini SS, 2008. Planting date, mulch, and herbicide rate effects on the growth, yield, and physicochemical properties of menthol mint (Mentha arvensis). Weed Technol. 22:691-8.

Sönmez O, Turan V, Kaya C, 2016. The effects of sulfur, cattle, and poultry manure addition on soil phosphorus. Turk. J. Agri. Forestry. 40:536-41.

Turan V, Ramzani PMA, Ali Q, Irum A, KhanWUD, 2017. Alleviation of nickel toxicity and an improvement in zinc bioavailability in sunflower seed with chitosan and biochar application in $\mathrm{pH}$ adjusted nickel contaminated soil. Arch Agron Soil Sci. 64:1053-67.

TuranV, Khan SA, Mahmoodur R, PMA R, Fatima M, 2018. Promoting the productivity and quality of brinjal aligned with heavy metals immobilisation in a wastewater irrigated heavy metal polluted soil with biochar and chitosan. Ecotoxicol. Environ. Saf. 161:409-19. 